\title{
Contaminant bacteria in traditional-packed honey
}

\author{
Hening Tjaturina Pramesti, Karlina Hardjawinata, Putra Qadri Fath
}

Department of Oral Biology, Faculty of Dentistry Universitas Padjadjaran

\begin{abstract}
Honey may be contaminated by microorganisms during its harvesting, processing, and packaging. Honey selected for clinical purposes must safe, sterile, and contain antimicrobial activity, so it must be evaluated using laboratory testing. The aim of this descriptive laboratory study was to isolate and identify the bacterial contaminant in the traditional-packed honey dealing with the use of honey for medical purposes. the colony forming units of honey sample cultured on blood agar were counted using Stuart bacterial colony counter. The suspected bacterial colonies were isolated and identified based on cultural morphology characteristics. The isolates of suspected bacterial colonies were stained according to Gram and Klein method and then were examined by biochemical reaction. The results showed that there were two contaminant bacteria. Gram-positive cocci which were presumptively identified as coagulasenegative Staphylococci and gram-positive rods which were presumptively identified as Bacillus subtilis. In conclusion, the contaminant bacteria were regarded as low pathogen bacteria. Subtilin enzyme of $B$ subtilis may cause allergic reaction and coagulase-negative Staphylococci, Staphylococcus epidermidis is also an opportunist pathogen. Inevitably, for medical purposes traditional-packed honey must be well filtered, water content above $18 \%$, and standardized sterilization without loss of an antibacterial activity or change in properties.
\end{abstract}

Key words: Bacterial contaminant, traditional-packed honey

\section{INTRODUCTION}

Honey is a floral nectar or secretions of plants that is gathered and processed by honeybees 1,2 or one of bee honey products besides bee wax, royal jelly, and propolis. ${ }^{3}$ It has been used for thousands of years in traditional medicine for several purposes. The ancient Greeks, Roman, Chinese and Egyptians used honey to heal wounds and cure disease of the gut. ${ }^{4}$

Another author reported that 2000 years before bacteria were discovered to be the cause of infection, honey was used to treat infected wounds. ${ }^{5}$ Then, the ancient African of West Africa ate honey daily as supplementeng diet that might occurs in their daily food intake. They also prescribed it when rearranging a patient's daily food regimen. ${ }^{6}$

Recently, there were scientific evidences supporting therapeutic uses of honey. Honey has been used as modern therapeutic agent because of its antibacterial activity. It has been proven that $91 \%$ of infected wounds treated with honey were free of infection within 7 days. Patients treated with honey experienced less irritation, more relief of pain, and no adverse effects. ${ }^{4,5}$ The anti-inflammatory activity of honey also reduces edema and exudates and prevents or minimizes 
hypertrophic scarring. ${ }^{7}$

Furthermore, honey has been reported to have an inhibitory effect to around 60 species of bacteria including aerobes and anaerobes, grampositives and gram-negatives bacteria. ${ }^{5}$

Some antibiotic-resistant bacteria, such as MRSA (Methicillin Resistant Staphylococcus aureus) and VRE (Vancomycin Resistant Enterococci) have been reported sensitive to honey. ${ }^{5,8}$ Specifically, Manuka and Pasture honeys at concentration of $2.7-5 \% \quad(\mathrm{v} / \mathrm{v})$ inhibited coagulase-negative Staphylococci. ${ }^{9}$ In Netherlands, a sterile wound ointment with a honey basis $50 \%(\mathrm{v} / \mathrm{v})$ was used in a multi-centre case report study of 139 nursing homes and General Practitioners practice patients suffering from ulcer, decubital ulcers, abrasion and burns. ${ }^{8}$

In dentistry, honey has been used to treat oral ulcer and periodontal disease. ${ }^{5}$ It has anticariogenic as well. Even though it contains more than $70 \%$ sugar, honey at high concentration had inhibitory effect on oral streptococci in vitro and salivary counts of total bacteria and Streptococcus mutants decreased after 1 hour application of honey. ${ }^{10}$ The antibacterial activity of honey can be caused by osmotic effect of its high sugar content, low $3.9 \mathrm{pH}$, and a thermo unstable substance named inhibine, hydrogen peroxide and enzyme such as catalysts. ${ }^{5,8,11}$

Honey is presumed to be sterile. However, it is a misconception. Honey may contain Bacillus $s p$, Clostridium, viable spore. ${ }^{5,8}$

It may also contain pesticides as well as antibiotic residues such as tetracycline used on bee. ${ }^{8}$ Commercially honey is sold in traditionalpacked and factory-packed honey. It is widely believed that factory-packed honey are more hygiene than traditional-packed honey due to have a better process or standardized in harvesting, processing, and packaging. ${ }^{3}$ Meanwhile, traditional-packed honey are usually processed by hand-pressing of a honeycomb. Then, honey are filtered using cloth. ${ }^{12}$ On the contrary, using traditional packed-honey as therapeutic agent is still an attractive option, may be because it is cheaper than factory-packed honey.

The use of honey for medical purposes, especially for the treatment of human, needs a sterile honey. It must be emphasized before problem arise for man. To achieve best results that traditional-packed honey can safely be applied as therapeutic agent, therefore the aim of this study was to isolate and identify contaminant bacteria in traditional-packed honey sold in Bandung, Indonesia.

\section{MATERIALS AND METHODS}

\section{Choosing of honey sample}

In the preliminary study we used and selected randomly three samples (Asy-syifa, Sumbawa, and Danau Sentarum) of Indonesian traditional-packed honey that were sold in Bandung city. Traditionalpacked honey is natural honeybee that is harvested, processed, and packed by beekeepers using hands in traditional way. To proof that contaminant bacteria are from honey sample, all honey samples were prepared for bacterial smear preparation on an object glass, and stained using gram-staining. ${ }^{13,14}$

Bacterial smear stained was examined using light microscope. It showed that all samples of honey were similar containing gram-positive rods (purple color). Then, one inoculating loop of each sample honey was cultured on blood agar plate, incubated for 24 hours at $37^{\circ} \mathrm{C}$ in incubator.

The result showed that the density of contaminant bacteria colonies of Danau Sentarum honey was lighter than the other honey samples. So, it is easily to isolate the suspected bacteria. Next, according to the density of bacterial colony, this descriptive laboratory study used Danau Sentarum honey as sample of study. This study was conducted in the Laboratory of Microbiology at Faculty of Dentistry, Universitas Padjadjaran in Jatinangor-Bandung.

\section{Characteristics of contaminant bacteria}

To determine the characteristic of contaminant bacteria in honey sample, one inoculating loop of honey was cultured on blood agar plate in Petri dish, incubated aerobically at $37^{\circ} \mathrm{C}$ for $18-24$ hours in incubator.

Culture of honey was made triple of different bottles of honey. Bacteria colonies or the colony forming units that grew on each of blood agar plate were counted using Stuart bacteria colony counter. After that, the characteristic of bacteria colonies were identified based on morphologies such as form, margin, elevation, size, color or 
pigment and the ability of microorganism to lyses blood in culture. $13,14,15$

\section{Microscopic and biochemical identification}

One inoculating loop of isolate of each suspected bacterial colony was smeared on an object glass for bacterial smear preparation and stained using Gram staining.If Gram-staining of bacterial colony shows gram-positive (purple color) coccus, next, the isolate of bacterial colony are prepared for biochemical identification, these are catalase and coagulase test. Catalase test was used to differ genus of Staphylococcus (catalasepositive) and Streptococcus (catalase-negative). Hydrogen peroxide $3 \%$ was dropped on bacterial suspension in $0.85 \% \mathrm{NaCl}$ on an object glass.

The reaction is catalase-positive if air or oxygen bubbles are produced. Coagulase test was used to differ Staphylococcus aureus (coagulasepositive) and Staphylococcus epidermidis or Staphylococcus saprophyticus (coagulase-negative Staphylococci). On object glass containing a heavy bacterial suspension was dropped $0.1 \mathrm{ml}$ blood plasma. Staphylococcus aureus can coagulate blood plasma or coagulase test is positive. If the result of coagulase test is negative, then it is suspected that isolate bacteria is Staphylococcus epidermidis or Staphylococcus saprophyticus. In this study, we did not differentiate both of last species. Next, these last species are called coagulase-negative staphylococci.

If the gram-staining result shows grampositive rods, the isolate of bacterial colony are prepared for further identification, spore staining and mannitol test. Spore staining according to Klein's method was used to differentiate sporeforming bacilli and non spore-forming bacilli. Suspected bacterial smeared on object glass was stained with Klein-spore staining. Spores will appear red and vegetative cells will appear blue. One inoculating loop of isolate of bacterial colony added to mannitol solution in glass tube, incubated for 24 hours at $37^{\circ} \mathrm{C}$.

Thereafter, if phenol red indicator in mannitol solution turn to yellow color, it is identified that bacteria are mannitol fermenter (mannitol-positive) or bacteria is suspected as Bacillus subtilis or Bacillus megaterium. Next, Voges-Proskauer test is used to differentiate these bacteria. Mannitol test is negative if isolate bacteria is Bacillus cereus. ${ }^{13,14,15}$

The schema for the identification of contaminant bacteria in traditional-packed honey in this study is presented in figure 1.

\section{RESULTS}

\section{Characteristics of contaminant bacteria}

The blood agar culture of three traditionalpacked honey can be seen in Figure 2. Then, there were two different colonies of contaminant bacterial of honey samples (Table 1 and Figure 3). First type colonies or A type colonies are round, about $1.5 \mathrm{~mm}$ in diameter, and have an irregular margin, a white grey pigment, a flat elevation. The A type colonies were B-hemolytic on blood agar plates.

The second type colonies or B type colonies are round, about $1.4 \mathrm{~mm}$ in diameter, and have an entire margin, a white pigment, a convex elevation. In contrast, B type colonies were unhemolytic on blood agar plates. The first replication of honey sample contains both A type colonies and B type colonies. While the second and third replication of honey sample contain only B type colonies (Table 2 and Figure 3).

The number of colonies on each honey sample on blood agar plate were presented in Table 2. In first replication of honey sample showed that the number of $A$ type colony were greater than the number of $B$ type colony. Then, the number of A type colony in the second and third replication are almost twice of the number of A colony in the first replication.

\section{Microscopic examination and biochemical test}

The Gram-staining result showed that the isolate of A type bacterial colony is gram-positive rods and arranged in chains. Klein staining result showed that they are spore-former. Then, the mannitol test showed that A bacterial colony is positive or they change phenol red indicator to yellow color (Figure 4).

The isolate of bacteria of B type colony showed gram-positive coccus and arranged in grape fruit-like clusters. Then, the bacteria produced air bubbles in catalase test or positivecatalase. Coagulase test performed that bacteria suspension did not coagulate blood plasma or coagulase-negative (Figure 5). 
Figure 1. The scheme for the identification of contaminant bacterial in traditional-packed honey
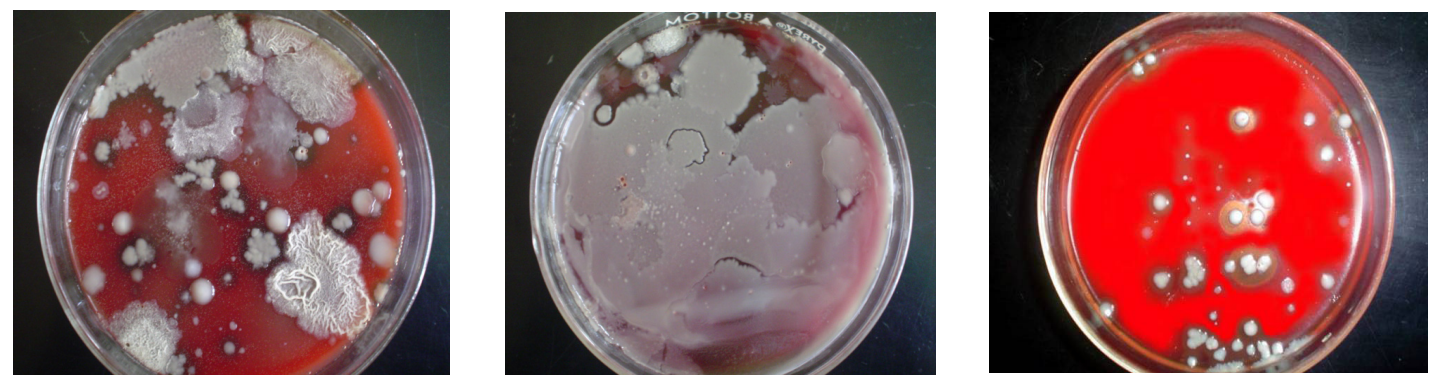

Figure 2. Characteristics of three kinds of traditional-packed honey that are sold in Bandung city a. Asy-syifa; b. Sumbawa; c. Danau Sentarum
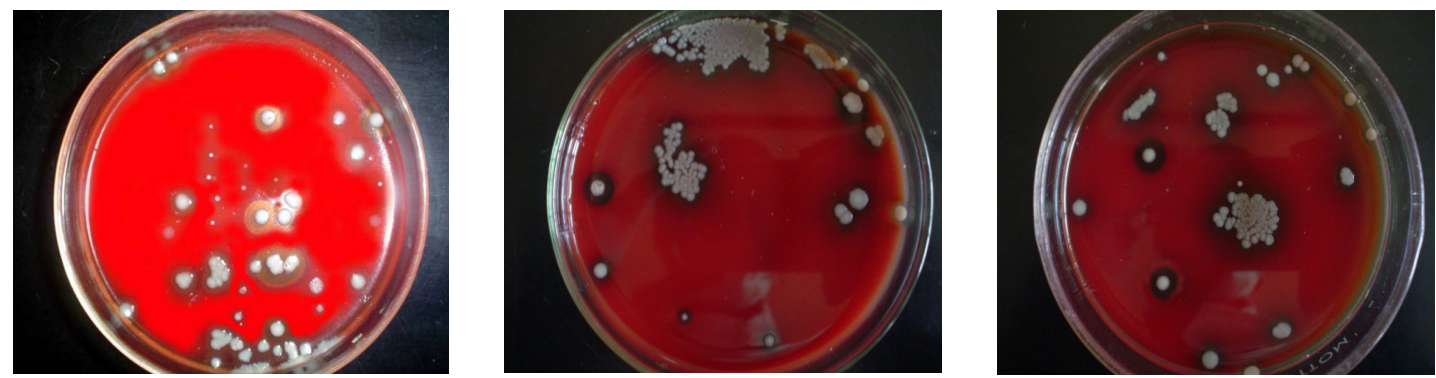

Figure 3. A and B types colonies of three replications of honey samples cultured on blood agar plate 

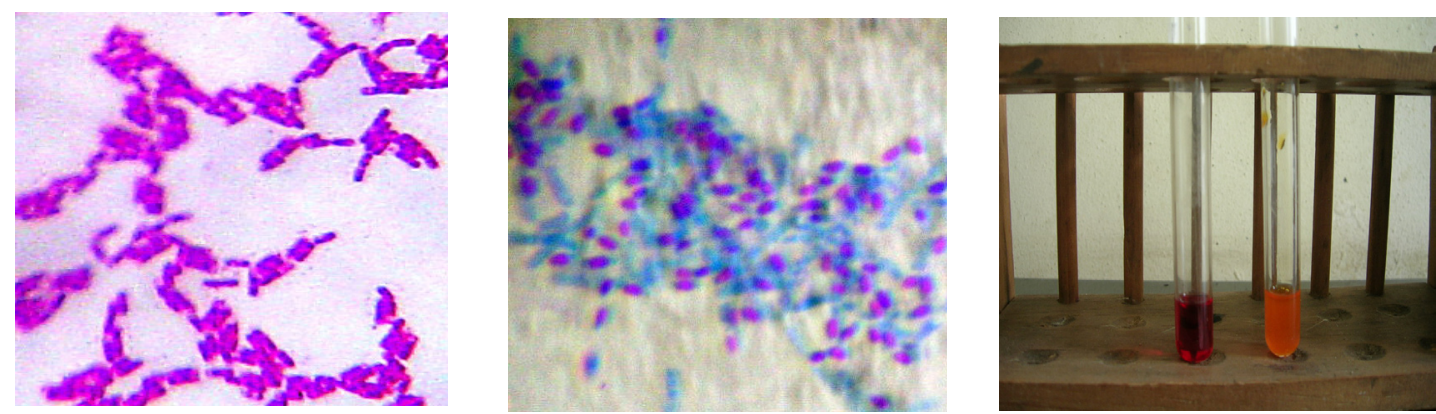

Figure 4. The results of microscopic examination and biochemical test of A type colony. a. Gram-staining positive rods (purple); b. Klein-staining (white arrow-spores-red/pink); c. Mannitol test (white arrow-sample)
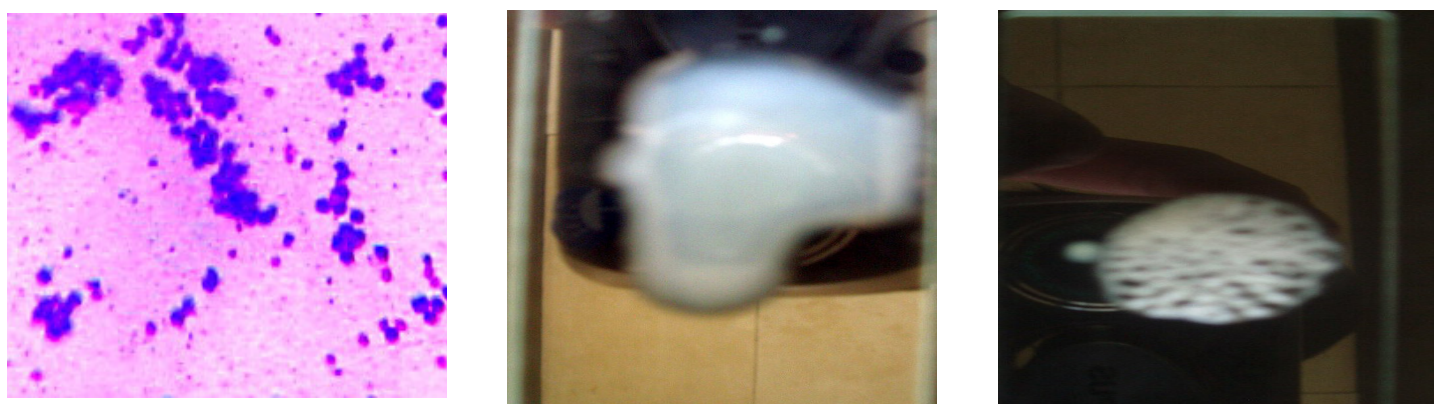

Figure 5. The results of microscopic examination and biochemical test of B type colony. a. Gram-staining positive coccus (purple); b. Catalase test-positive (air bubbles); c. Coagulate test-negative or no cult blood plasma

Table 1. Characteristics of contaminant bacterial colonies of honey samples on blood agar plates

\begin{tabular}{|c|c|c|c|c|}
\hline \multirow{2}{*}{ Colony } & \multirow{2}{*}{ Characteristics of culture } & \multicolumn{3}{|c|}{ Replication of honey sample } \\
\hline & & 1 & 2 & 3 \\
\hline A & $\begin{array}{c}\text { Form } \\
\text { Diameter } \\
\text { Margin } \\
\text { Pigment } \\
\text { Elevation } \\
\text { Ability to lyses blood }\end{array}$ & $\begin{array}{l}\text { Round } \\
1-5 \mathrm{~mm} \\
\text { Irregular } \\
\text { Grey-White } \\
\text { Flat } \\
\text { Hemolytic }\end{array}$ & $\begin{array}{l}\text { Round } \\
1-5 \mathrm{~mm} \\
\text { Irregular } \\
\text { Grey-White } \\
\text { Flat } \\
\text { Hemolytic }\end{array}$ & $\begin{array}{c}\text { Round } \\
1-5 \mathrm{~mm} \\
\text { Irregular } \\
\text { Grey-White } \\
\text { Flat } \\
\text { Hemolytic }\end{array}$ \\
\hline B & $\begin{array}{c}\text { Form } \\
\text { Diameter } \\
\text { Margin } \\
\text { Elevation } \\
\text { Ability to lyses blood }\end{array}$ & $\begin{array}{l}\text { Round } \\
1-4 \mathrm{~mm} \\
\text { Entire } \\
\text { White } \\
\text { Convex } \\
\text { Unhemolytic }\end{array}$ & & \\
\hline
\end{tabular}

Table 2. The number of colonies of on blood agar plates

\begin{tabular}{cccc}
\hline \multirow{2}{*}{ Colony } & \multicolumn{3}{c}{ The number of colonies } \\
\cline { 2 - 4 } & Sample 1 & Sample 2 & Sample 3 \\
\hline A & 52 & 101 & 104 \\
B & 10 & - & - \\
Total & 62 & 101 & 104 \\
\hline
\end{tabular}

Based on characteristic on blood agar plate, gram-staining and Klein-staining examination, and mannitol test as well, the isolate of A type colony was presumptively identified as Bacillus subtilis. While, the result of characteristic of B type colony on blood agar plate, catalase and coagulase test, it was presumptively identified as coagulase- negative Staphylococci. ${ }^{13,14,15}$

\section{DISCUSSION}

It has been proved that samples of Indonesian traditional-packed honey contain gram-positive rods bacteria. In further identification, sample 
honey cultured on blood agar plate showed that the growth of bacteria were vary. It is presented by the number of colony in each blood agar plate. The number of Bacillus subtilis colonies are greater than the number of coagulase-negative Staphylococci colonies.

It can be assumed that $B$. subtilis is the highest contaminant bacteria in Indonesian traditional-packed honey. $B$. subtilis are saprophytic organism prevalent in soil, water, and air. ${ }^{13,16,17}$ So, it is possible that honey can also be contaminated by $B$. subtilis from air or nonsterile bottle. Honey may occasionally contain B. subtilis result of non-sterile condition during harvesting, processing, and packaging. ${ }^{3}$ Another explanation it may be caused by $B$. subtilis endospore contaminating honey and it germinated during incubation. Honey do not allow vegetative bacteria to survive, but it does contain viable spores. ${ }^{5}$ Spores display a spectacular ability to survive in hostile environment for long periods. They also resistant to many of chemical agents used as disinfectant, physical environments including high temperature, ionizing radiation, and desiccation. . $^{518,19,20}$

Coagulase-negative Staphylococci found in traditional-packed honey may due to Coagulasenegative Staphylococci of beekeeper skin contaminated honey while harvesting, processing or packaging. One of human coagulase-negative staphylococcal species, S. epidermidis is a human normal flora on the skin surface, respiratory and gastrointestinal tract and it is spread by contact. $13,16,17,20,21$

Contaminant bacteria are found in Indonesian traditional-packed honey even honey scientifically proof has an antibacterial activity. It could be explained that honey is produced from many different floral sources and its antibacterial activity varies with origin and processing. ${ }^{5,9}$ Another explanation is that there is a tendency some traditional-packed honey have been added water to increase volume. Diluting honey with water will decrease the antibacterial activity and it will promote the microbial growth. Honey containing water above $18 \%$ is easily to get a fermentation. $^{3}$

B. subtilis is not considered as human pathogen, it may contaminated food but rarely cause food poisoning. However, it produces the proteolytic enzyme, subtilin which has been shown to be a potent occupational allergen. ${ }^{17} \mathrm{On}$ the other hand, coagulase-negative Staphylococci species, especially, S. epidermidis is opportunist pathogen. ${ }^{16,17,20,21}$

It means that the bacteria cause infection if the opportunity arises. S. epidermidis may infect man with low immunity or specific conditions. For example S. epidermidis can cause infection of man with intravenous catheter or prosthetic implants. ${ }^{16,21}$ Inevitably, honey especially for medical uses must sterile and has antimicrobial activity. Gamma radiation has been used to sterilize some brands of honey. It kills clostridial spores without loss of any of the antibacterial activity or changes in honey properties. ${ }^{5,8}$

\section{CONCLUSION}

Contaminant bacteria found in Indonesian traditional-packed honey and were presumptively identified belong to Bacillus subtilis and coagulasenegative Staphylococci species. To enhance the quality of Indonesian traditional-packed honey for medical purposes, honey must be well filtered, contain no water above $18 \% \mathrm{v} / \mathrm{v}$, and treated by standardized sterilization.

\section{AKNOWLEDGEMENT}

This study was supported by The Indonesian Loan Fund for Education (PHK-A2 Faculty of Dentistry Universitas Padjadjaran )

\section{REFERENCES}

1. Purbaya JR. Mengenal dan memanfaatkan khasiat madu alami. Bandung: Pionir Jaya; 2002.

2. CODEX A. Food category details. 2006 [cited 2006 Agu 26]. Available from: http://www. GSFA.

3. Krell R. Value-added products from beekeeping Rome. 1996 [cited 2006 Agu 26]. Available from: http://www.fao.org.

4. McCarthy J. Antibacterial effects of honey: Medical fact or fiction. 1995 [cited 2007 Apr 04]. Available from: http://www.linternet antibacterialhoneybyjuly-mht.

5. Molan PC. Honey as a topical antibacterial 
agent for treatment of infected wounds. New Zealand: 2001 [cited 2006 Mar 21]. Available from: http: / / www. worldwidewounds. com / 2001/ november/molan/honey-astopical-agent.html.

6. Sawandi T. Honey-nature's perfect food [cited 2006 Mar 21]. Available from: http://www. blackherbals.com.

7. Molan PC. The evidence supporting the use of honey as a wound dressing. Int $\mathrm{J}$ Lower Extremity Wound 2006;5(1):40-54 [cited 2007 Apr 03]. Available From: http://www.ijl. sagepub.com.

8. Overgaauw PAM, Kirpensteijn J. Application of honey in the treatment of skin wounds. Netherland: 2006 Apr 16(1) [cited 2007 Apr 04]. Available from: http://www.European. Journal.nl.com/EJCAP.

9. French VM, Cooper RA, Molan PC. The antibacterial activity of honey against coagulase-negative Staphylococci. J Antimicrob Chemotherapy 2005;56(1):228-31 [cited 2007 Apr 04]. Available from: http:// www.fjac.oxfordjournals.orgs.

10. Steinberg D, Kaine G, Gedalia I. Antibacterial effect of propolis and honey on oral bacteria Am J Dent 1996 Dec 9(6):236-39 [cited 2007 Apr 04]. Available from: http://www.pubmed. gov.

11. Jeffrey AE, Echazarreta CM. Medical uses of honey. 1996 [cited 2006 Jun 24]. Available from: http: / /www.uady.mx.

12. Suryanarayana MC. Monograph on traditional sciences and technologies of India-honey industry India. 1994 [cited 2006 Jun 24]. Available from: http: / /www.mandafamily.com.

13. Koneman EW, Allen SD, Janda WM. Schreckenberger PC, Winn WC. Color atlas and textbook of diagnostic microbiology. $5^{\text {th }}$ ed. Philadelphia: Lippincott-Raven Publishers; 1997. p. 16-120,539-76,651-64, 1296-395.

14. Cappucino JG, Sherman N. Microbiology a laboratory manual. $6^{\text {th }}$ ed. San Francisco: Pearson Education Inc. Benjamin Cummings; 2002. p.13-85.

15. Hart T, Shears P. Color atlas of medical microbiology (Atlas berwarna mikrobiologi kedokteran). Jakarta: Penerbit Hippocrates; 1997. p. 71-181.

16. Brooks GF, Butel JS, Ornston LN. Jawetz, Melnick \& Adelberg's medical microbiology. $23^{\text {th }}$ ed. London: Appleton \& Lange; 2004. p. 223-47.

17. Todar K. Todar'online textbook of bacteriology. University of Winconsin-Madison. 2005 [cited 2006 Sep 10]. Available from: http://www. textbookofbacteriology. net.

18. Miller $\mathrm{CH}$, Palenik CJ. Infection control and management of hazardous materials for the dental team. Toronto: Mosby-Year Book Inc. 1994. p. 16-7.

19. Lambert PA. Bacterial resistance: resistance of bacterial spore to chemical agents. In: Fraise AP, Lambert PA, Maillard JY, editors. Russell, Hugo and Ayliffe's principles and practice of disinfection, preservation, and sterilization. $4^{\text {th }}$ ed. Oxford UK: Blackwell Publishing Ltd; 2004. p. 184-90.

20. Samaranayake LP. Essential microbiology for dentistry. $2^{\text {nd }}$ ed. London: Churchill Livingstone; 2002. p. 95-101.

21. Levinson W, Jawetz E. Examination and board review medical microbiology and immunology. $5^{\text {th }}$ ed. London: Prentice-Hall International Inc.; 1998. p. 78-80. 